\title{
WINTER SONGS \\ OF THE PINE GROSBEAK
}

PETER TAYLOR, P.O. Box 597, Pinawa, MB. R0E 1 LO

Both in appearance and voice, the Pine Grosbeak is one of Canada's most attractive winter birds. Bent's account of this species includes several tributes to the beauty of its songs. ${ }^{1}$ In winter most of the Pine Grosbeak's vocalizations are flight or contact calls but its repertoire includes some quiet yet complex songs of the kind often called "whisper song." An interesting feature of these songs is the frequent imitation of other birds' calls. ${ }^{2}$ Because so few birds sing in winter in Manitoba, I have kept notes on this behaviour over an extended period. Here, I summarize 78 observations of whisper singing by Pine Grosbeaks at, or near, Pinawa, Manitoba between 1978 and 1995 . They include 38 observations $(49 \%)$ of songs that included mimicry of other species. "Typical" territorial song was noted less frequently, about 15 times.

The Pine Grosbeak is a common winter visitor to the Pinawa area. My 20 years of migration records indicate median first-arrival and last- departure dates of 24 October and 19 March, respectively. Breeding-season records in southeastern Manitoba are exceedingly rare.

Observations Whisper song of the Pine Grosbeak is normally audible from about $25 \mathrm{~m}$ under ideal conditions. Some especially soft renditions may be barely audible at $10 \mathrm{~m}$. The song consists of a steady stream of soft whistles, warbled phrases and call-notes, often including muted versions of typical Pine Grosbeak flight- calls and imitations of the calls of other bird species. This medley is uttered more or less continuously, sometimes for 5 minutes or more at a stretch. In contrast, typical song consists of brief but rich warbled phrases with a "wild" quality, suggesting a loud Purple Finch, and is clearly audible at $100 \mathrm{~m}$ or more. A few Pine Grosbeak songs were intermediate in volume and complexity between the whisper and typical songs, and were therefore difficult to classify.

Pine Grosbeaks usually utter their whisper songs while perched in trees, either alone or in small groups and otherwise unoccupied. Sometimes they sing, without interruption, while feeding on ash or lilac seeds etc. Singing has been noted in sunshine, cloudy conditions, and even during a snowstorm and at temperatures down to $-35^{\circ} \mathrm{C}$. In 47 cases where the individual songsters could be distinguished, 30 were adult males (i.e. second winter or older), four were definitely subadult males, and 13 were either females or subadult males.

Observations of whisper singing span the wintering period, from 14 October to 10 March (the former date, coincidentally, is a local earlyarival record). However, 68 of the 78 observations (87\%) occurred between 29 January and 10 March, indicating increased singing during the month or so prior to migration which is usually under way by late February. Whisper singing has been noted 


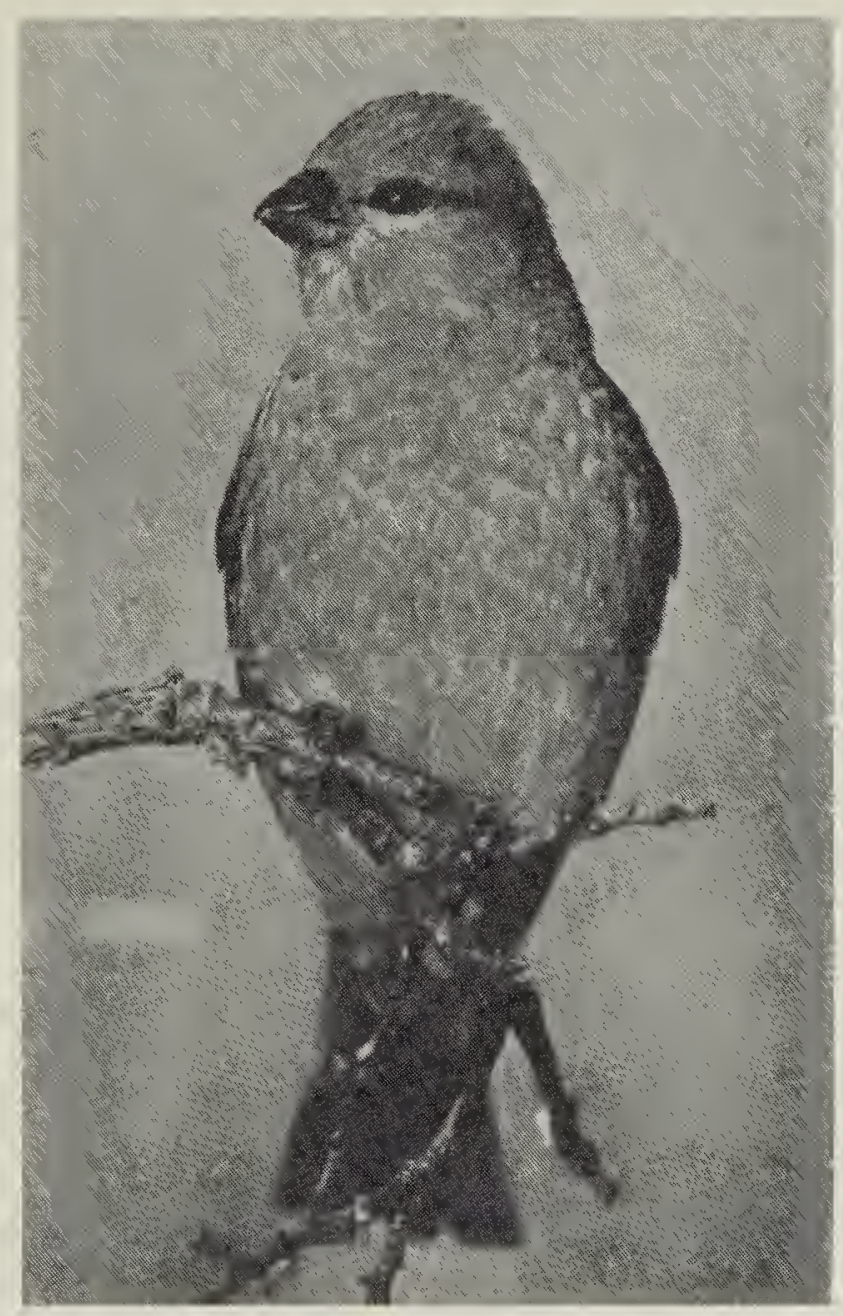

Pine Grosbeak

Frank Walton

throughout the daylight hours, as early as 7:30 a.m. (just before sunrise) 14 February 1995 and as late as 5:15 p.m. (half an hour before sunset) 24 February 1981. A majority of observations (approximately $80 \%$ ) were between 9:00 a.m. and 12:00 a.m. but this is partly a reflection of my own activities.

In most cases, only one whisper singing bird was heard on a given day. On six occasions, three or four well separated songsters were noted in one day (each individual is included as a separate observation in the totals discussed here). An exceptional number of singing Pine Grosbeaks was heard in Pinawa on 4 March 1995. At least 18 individuals out of 80 birds seen in the space of 90 minutes (8:00 A.m. to 9:30 a.m.) were singing; 14 were uttering whisper songs and four intermediate songs. At least nine of the 14 whisper singers included mimicry in their repertoires. Of the 18 singers, seven were males, four probably females and seven undetermined. Nearly every group of Pine Grosbeaks I approached that day included at least one singer. This exceptional record is probably linked to a later-thanusual departure of Pine Grosbeaks from southern Manitoba, prompted by unseasonably cold weather.

All of the bird species imitated by the Pine Grosbeak share its summer range. Most frequently mimicked were the calls of American Robin (34 occasions) and Gray Jay (14). Less frequently mimicked were Lesser Yellowlegs (6), White-winged Crossbill (5), Northern Flicker (5), Common Redpoll (4), Hairy Woodpecker (4), Olive-sided Flycatcher (4), Greater Yellowlegs (1), and Yellowbellied Sapsucker (1). As many as five different species have been imitated in a single bout of song. The song is so softly uttered, and richly varied, that other imitations could easily have been overlooked.

On 40 of 78 occasions (51\%), whisper singing was noted without evidence of vocal mimicry. However, this total includes instances when the song was heard only briefly or with interfering background noise. Therefore mimicry is probably even more frequent than this percentage suggests.

Discussion Complex sub-songs, sometimes described as whisper singing, represent a phase in the development of song repertoire in young individuals of many passerine species, often commencing just a few weeks after fledging. ${ }^{3}$ However, it is known that this behaviour is not restricted to juvenile birds, as illustrated by the present study. The timing of most of my observations suggests a link to the onset of breeding condition in late winter. 
I am aware of one other published report of vocal mimicry by whisper singing Pine Grosbeaks; the singer was one of a pair at a nest near Roddickton, Newfoundland on 24 June 1981. ${ }^{4}$ The species mimicked in that case were American Robin, Gray Jay, Ruby-crowned Kinglet, Greater Yellowlegs, and possibly Red Crossbill. Bent includes a reference to a loud imitation of American Goldfinch flight calls by a group of Pine Grosbeaks but this may refer to similar phrasing of the two species' calls rather than true mimicry. ${ }^{1}$

The observations described here indicate that whisper singing, often iricluding mimicry of other birds' calls, is a fairly common behaviour of Pine Grosbeaks in late winter. Whatever its biological function may be, it certainly uplifts the human spirit on a cold winter day in Manitoba. I would be pleased to hear of any related observations on Pine Grosbeak song.

Acknowledgements I thank Reto Zach and Rudolf $F$. Koes for helpful comments on a draft of this article

1. BENT, A.C. et al. Life Histories of North American Cardinals, Grosbeaks, Buntings, Towhees, Finches, Sparrows, and allies (O.L. AUSTIN, Jr., ed.). U.S. National Museum Bulletin 237, Part One. Smithsonian Institution, Washington D.C. Pp. 326-346.

2. TAYLOR, P. 1979. Interspecific vocal mimicry by Pine Grosbeaks. Can. Field-Nat. 93:436-437.

3. TERRES, J.K. 1982. The Audubon Society encyclopedia of North American Birds. Alfred A. Knopf, New York, N.Y. Pp 833-834.

4. WELLS, J. 1981. An observation of vocal mimicry in Pine Grosbeak. The Osprey Newfoundland Natural History Society Quarterly 12:82-84.

It is diversity by which life builds and saturates the rain forest. And diversity has carried life beyond, to the harshest environments on earth. Rich assemblages of animals swarm in the shallow bays of Antarctica, the coldest marine habitats on earth. Perch-like notothenioid fishes swim there in temperatures just above the freezing point of salt water but cold enough to turn ordinary blood to ice, because they are able to generate glycopeptides in their tissues as antifreeze and thrive where other fish cannot go. Around them flock dense populations of active brittlestars, krill, and other invertebrate animals, each with protective devices of its own. Wilson, E.O. 1992. The diversity of life. W.W. Norton and Company, New York. 424 pp. 